\title{
A new look at an old dog: Bonn-Oberkassel reconsidered
}

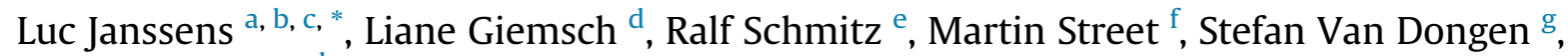 \\ Philippe Crombé ${ }^{\mathrm{h}}$
}

\author{
a Department of Archaeology, Einsteinweg 2, 2333 CC Leiden, The Netherlands \\ b Department or Archaeology Sint-Pietersnieuwstraat 35, 9000 Ghent, Belgium \\ ${ }^{c}$ Evidensia Specialist Referral Clinic for Companion Animal Surgery, Bijdorp-West 12, 2992 LC, Barendrecht, The Netherlands \\ d Archäologisches Museum Frankfurt, Karmelitergasse 1D-60311 Frankfurt Am Main, Germany \\ e LVR-Landesmuseum Bonn, Rheinisches Landesmuseum für Archäologie, Kunst- und Kulturgeschichte \\ Bachstraße 5-953115 Bonn, Germany \\ ${ }^{\mathrm{f}}$ Monrepos Archaeological Research Centre and Museum for Human Behavioral Evolution, Schloss Monrepos, 56567 Neuwied, Germany \\ ${ }^{g}$ Evolutionary Ecology Group, Antwerp University, Universiteitsplein 1, 2610 Antwerp, Belgium \\ hepartment of Archaeology, Ghent University, Sint-Pietersnieuwstaat 35, 9000 Gent, Belgium
}

\section{A R T I C L E I N F O}

\section{Article history:}

Received 13 October 2017

Received in revised form

11 January 2018

Accepted 15 January 2018

Available online $\mathrm{xxx}$

We dedicate this paper to our dear

colleague Becky Miller $\nmid 2017$.

\section{Keywords:}

Domestication

Human-animal-bond

Pleistocene

Wolf

Dog

Upper palaeolithic

\begin{abstract}
A B S T R A C T
The Bonn-Oberkassel dog remains (Upper Pleistocene and 14223 +- 58 years old) have been reported more than 100 years ago. Recent re-examination revealed the tooth of another older and smaller dog, making this domestic dog burial not only the oldest known, but also the only one with remains of two dogs. This observation brings the total known Magdalenian dogs to nine.

Domestication of dogs during the final Palaeolithic has important implications for understanding preHolocene hunter-gatherers. Most proposed hunter-gatherer motivations for domesticating dogs have been utilitarian. However, remains of the Bonn-Oberkassel dogs may offer another view.

The Bonn-Oberkassel dog was a late juvenile when it was buried at approximately age 27-28 weeks, with two adult humans and grave goods. Oral cavity lesions indicate a gravely ill dog that likely suffered a morbillivirus (canine distemper) infection. A dental line of suggestive enamel hypoplasia appears at the 19-week developmental stage. Two additional enamel hypoplasia lines, on the canine only, document further disease episodes at weeks 21 and 23. Pathological changes also include severe periodontal disease that may have been facilitated by immunodeficiency.

Since canine distemper has a three-week disease course with very high mortality, the dog must have been perniciously ill during the three disease bouts and between ages 19 and 23 weeks. Survival without intensive human assistance would have been unlikely. Before and during this period, the dog cannot have held any utilitarian use to humans.

We suggest that at least some Late Pleistocene humans regarded dogs not just materialistically, but may have developed emotional and caring bonds for their dogs, as reflected by the survival of this dog, quite possibly through human care.
\end{abstract}

(c) 2018 Elsevier Ltd. All rights reserved.

\section{Introduction}

Ancient gray wolves are the likely ancestors of the domestic dog. The domestic dog first was described with reasonable certainty

\footnotetext{
* Corresponding author. Department of Archaeology, Einsteinweg 2, 2333 CC Leiden, The Netherlands.

E-mail addresses: coati1@icloud.com (L. Janssens), liane.giemsch@stadtfrankfurt.de (L. Giemsch), ralf-w.schmitz@lvr.de (R. Schmitz), street@rgzm.de (M. Street), Stefan.vandongen@uantwerpen.be (S. Van Dongen), Philippe.Crombe@ UGent.be (P. Crombé).
}

from the Magdalenian (Botigué et al., 2016; Boudadi-Maligne et al., 2012; Boudadi-Maligne and Escarguel, 2014; Célérier, 1994; Crockford, 2006; Druzhkova et al., 2013; Horard-Herbin et al., 2014; Larson et al., 2012; Morey, 2010; Morey and Jeger, 2015; Müller, 2005; Napierala and Uerpmann, 2012; Perri, 2016; PionnierCapitan, 2010; Pionnier-Capitan et al., 2011; Thalmann et al., 2013). Earlier Pleistocene dogs have been reported from the Aurignacian (Camarós et al., 2016; Germonpré et al., 2009, 2012, 2015, 2017; Ovodov et al., 2011; Pidoplichko, 1969; Sablin and Khlopachev, 2002) but their classification is contentious (e.g., Crockford and Kuzmin, 2012; Boudadi-Maligne and Escarguel, 
2014; Drake et al., 2015; Frantz et al., 2016; Morey and Jeger, 2015; Napierala and Uerpmann, 2012; Perri, 2016).

Exact geographical locations of wolf domestication are debated, with arguments that favor East Asia and the Middle East (Savolainen et al., 2002; Vonholdt et al., 2010; Wang et al., 2013), Central Asia (Shannon et al., 2015), South China (Pang et al., 2009), and Europe (Thalmann et al., 2013). The number of domestication events also is unresolved, with some investigators arguing for one (Botigué et al., 2016; Freedman et al., 2014), others reporting two such events (Frantz et al., 2016; Pionnier-Capitan, 2010), and still others proposing multiple events (Clutton-Brock, 1995; Dayan, 1994; Vila et al., 1999).

Based on present knowledge, the most probable dog progenitors were European (Thalmann et al., 2013) or Asian (Savolainen et al., 2002; Duleba et al., 2015) wolves whose DNA lineage has not been found in recent wolf populations, and thus this ancestor is either extinct (Morey and Jeger, 2015) or still undiscovered (Morey and Jeger, 2015).

Human motivations for domesticating/taming/socializing wolves are not yet fully understood, and while in modern societies, dogs fulfill important psycho-emotional human needs and also a social bond has been suggested for the early human-wolf interactions (Morey, 2010; 83), most of those who have studied early dog domestication have proposed utilitarian hypotheses (Bicho, 2013; Crabtree and Campana, 1987; Gautier, 1998; Germonpré et al., 2012; Grimm, 2015; Müller, 2005; Morey, 2010; Olsen, 1985; Shipman, 2010; Zeder, 2012) that include hunting (Bicho, 2013; Crabtree and Campana, 1987; Derr, 2011; Driscoll et al., 2009; Horard-Herbin et al., 2014; Lupo, 2011; Oliver Foix, 2014; Olsen, 1985; Shipman, 2015); guarding (Derr, 2011; Driscoll et al., 2009; Horard-Herbin et al., 2014; Shipman, 2015); transport
(Bicho, 2013; Crabtree and Campana, 1987; Germonpré et al., 2012; Morey, 2010; Pitulko and Kasparov, 2017; Shipman, 2015); waste disposal (Crabtree and Campana, 1987; Derr, 2011; Grimm, 2015; Horard-Herbin et al., 2014; Mivart, 1890; Müller, 2005; Morey, 2006); warfare (Grimm, 2015; Horard-Herbin et al., 2014); herding (Oliver Foix, 2014); clothing (pelts) (Morey, 2010; Müller, 2005; Müller et al., 2006; Pionnier-Capitan, 2010); warmth (bedwarmer) (Crabtree and Campana, 1987; Horard-Herbin et al., 2014; Manwell and Baker, 1984; Müller, 2005); entertainment (HorardHerbin et al., 2014); pest control (Crockford, 2006; Derr, 2011; Mivart, 1890); food (canophagy) (Degerbřl, 1961b; Derr, 2011; Horard-Herbin et al., 2014; Mivart, 1890; Morey, 2010; Müller, 2005); symbolic reasons such as social status, or emotional and spiritual reasons (Morey, 1992, 2006, 2010).

We question the utilitarian-materialistic view and provide evidence that early dogs may have been regarded and treated as a pet (defined by the Merriam-Webster dictionary as a domesticated animal, kept for pleasure rather than utility) from their very beginning, already in the Pleistocene. Our argument is based on the pathology diagnosed in the Bonn-Oberkassel dog. The incomplete remains of this dog were found one hundred years ago, on the eve of the First World War, together with the skeletons of an older man and a younger woman. The site was a basalt quarry at Oberkassel, today a suburb of Bonn (Fig. 1).

The finds first were assigned to the Upper Palaeolithic based on comparisons involving portable art objects (Verworn et al., 1919). More recent studies assign the finds to cultural remains from the Late Palaeolithic (Giemsch et al., 2015; Street et al., 2015). While the canid mandible initially was assigned as a wolf (Verworn et al., 1919), more recent research favors a domestic dog (Nobis, 1981; Benecke, 1987; Street, 2002; Henke et al., 2006). Revised

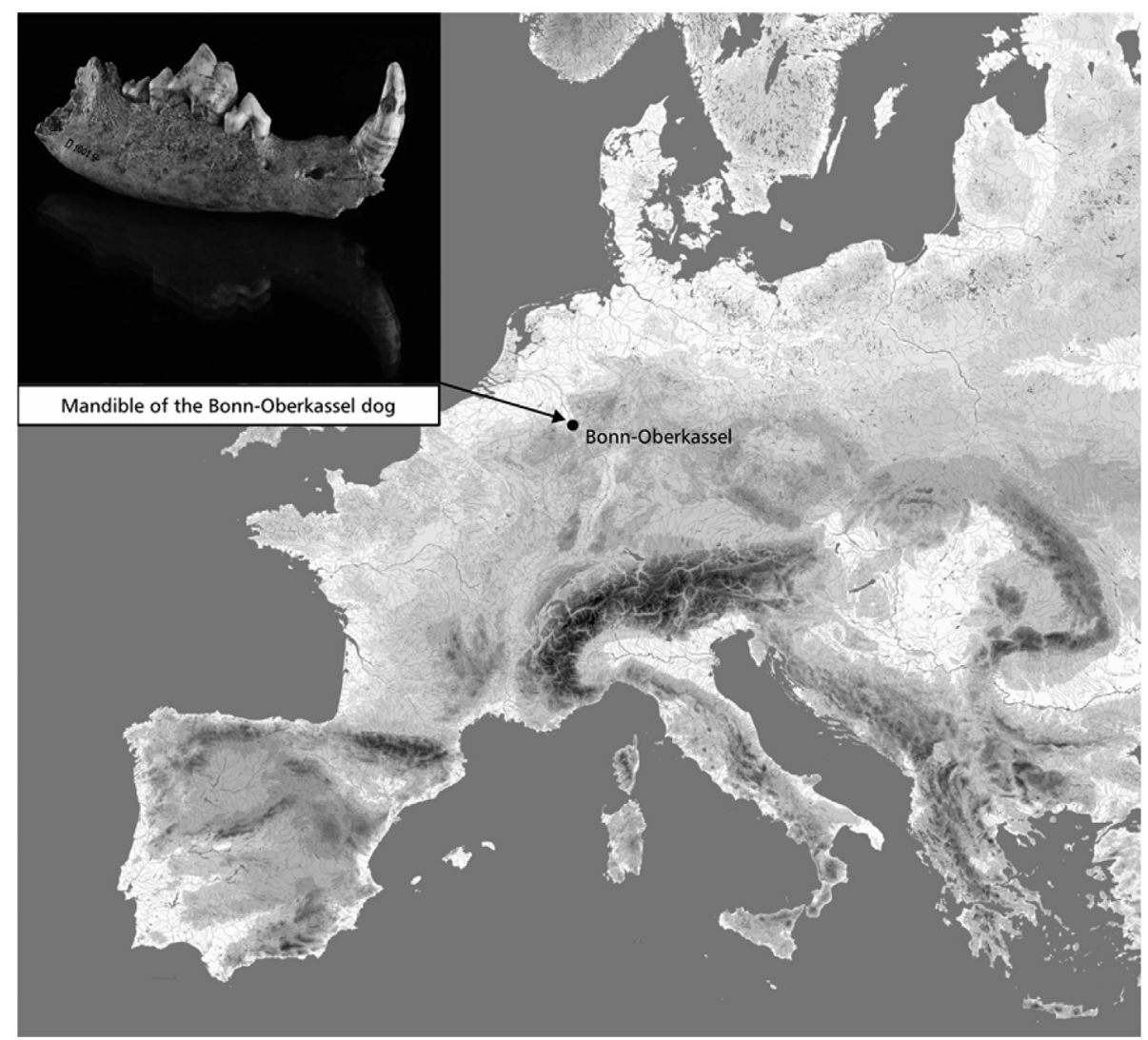

Fig. 1. The location of Oberkassel near Bonn, Germany, the site of a double human burial and the dog remains described here. Copyright: openstreetmaps.org. 

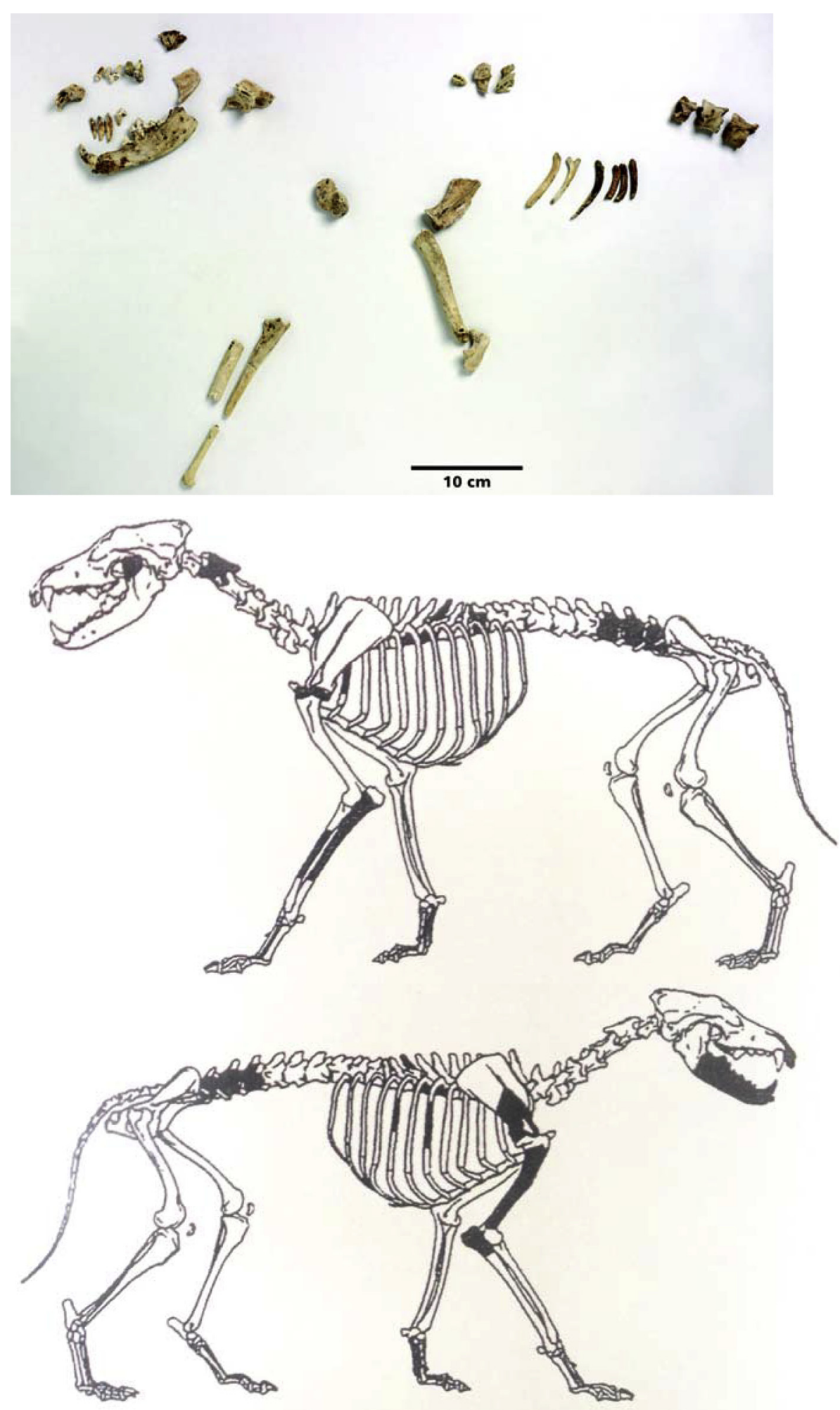

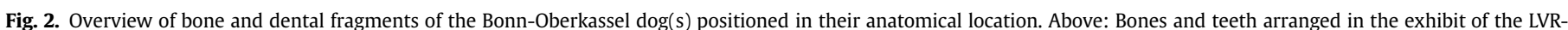

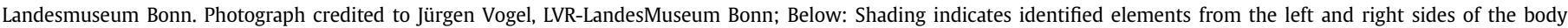
(adapted from Henke et al., 2006, Fig. 6).

evaluation of the excavated non-human material resulted in assignment of several previously-unidentified fragments to the Canis individual, creating a more complete picture of the remains (Fig. 2) (Street, 2002). Very recently, the Canis specimen has been evaluated by veterinary specialists, with the purpose of more accurate diagnosis.

We present results based on a preliminary study (Janssens et al., 2015), now adding corrected and new data. First, we conducted a 
thorough review of the dental pathology and differential diagnosis, framing details in a clinical context. This allowed us to assess how the represented dog must have been perceived and treated by Paleolithic hunter gatherers, particularly from the psychoemotional perspective. Second, we refine the data concerning age at death and severity of disease. Third, we report on a second BonnOberkassel dog that is of paramount importance, considering how few Magdalenian dogs have been described to date (eight over the last 100 years). Formerly unassigned bones from the find now can be assigned to the original canine, based on new analysis.

\section{Material and methods}

\subsection{Dating}

Four radiocarbon dates were performed on the canine bones (for details see Table 3), situating them between ca. 12900/12850 and ca. $11900 / 11850 \mathrm{cal}$ BC. Their weighted mean is between 12290 and 12050 cal BC $(2 \sigma)$ (Higham et al., 2015).

The female human remains were dated twice, situating them between ca. $12550 / 12150$ and 11800 cal BC. Their weighted mean is between 12160 and 11830 cal BC $(2 \sigma)$.

There is no statistical difference between the weighted age mean of the human and dog samples on a 1.68sigma level, and thus, the burial of the female human and dog can be considered to be a single event.

The dates are consistent with the very late Magdalenian, during the early part of the last Greenland (Meiendorf) Interstadial (GI 1e). During this time, global temperatures rose sharply and the Pleistocene Mammoth Steppe was being replaced by temperate woodland. The steppe-adapted Upper Palaeolithic (in Western and Central Europe at this time) transitioned to a Final Palaeolithic environment that supported bow and arrow hunting strategies and rapid spread into previously unoccupied parts of Northern Europe (Bicho, 2013; Miller, 2012; Street et al., 2012).

\subsection{Genetics}

The mitochondrial aDNA of the Oberkassel dog confirms its status as a domestic dog (Thalmann et al., 2013) and assigns it to the C clade of the dog genomic classification (Druzhkova et al., 2013; Duleba et al., 2015).

\subsection{Post-cranial skeletal fragments and age, weight and height of the dog}

Based on morphology and morphometry, 23 individuallyregistered bone specimens were identified as postcranial dog remains (Fig. 2). Open epiphyseal growth plates were observed on a number of bones, including the proximal humerus, all lumbar vertebrae (Fig. 3), and the caudal axis (C2). Closed growth plates

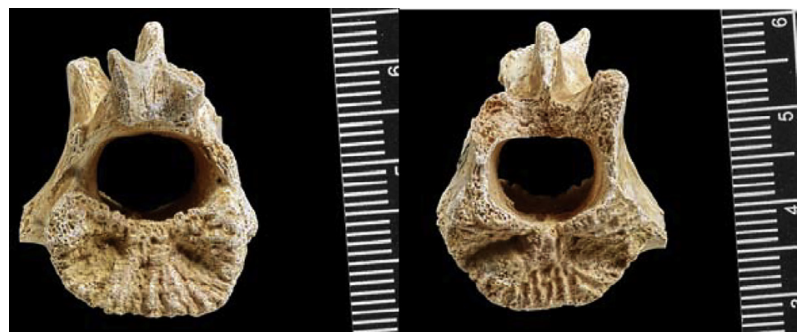

Fig. 3. Lumbar vertebra with open cranial (right) and caudal (left) epiphysis and open caudal epiphysis, indicative for an age under 7 months.

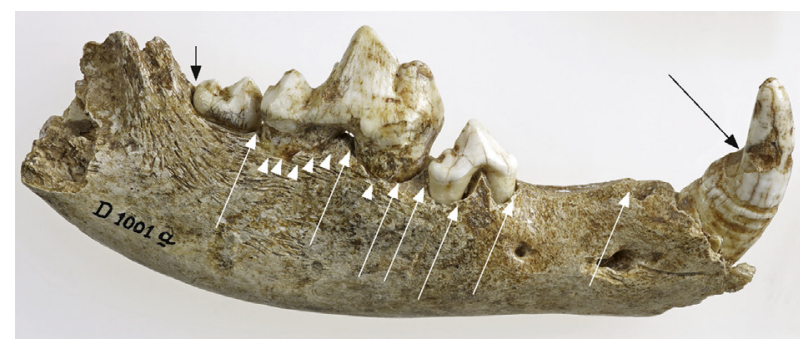

Fig. 4. Horizontal ramus of the right dog mandible in labial view. The black arrows point out alveolar rim bone loss in $\mathrm{C}, \mathrm{P}_{4}$ and $\mathrm{M}_{1}$, the white arrow points at the abrasion on the caudal aspect of the canine tooth (for details see text). Teeth present are from rostral to caudal: Canine $(C)$, Premolar $\left(\mathrm{P}_{4}\right)$, Molars $\left(\mathrm{M}_{1}, \mathrm{M}_{2}\right)$. Photograph credited to Jürgen Vogel, Artwork credited to Martin Pütz, LVR-LandesMuseum Bonn.

were noted on metacarpal bone, the proximal ulna, and the caudal glenoid. This young age is further supported by full dentition without attrition (Gipson et al., 2000) and a 50\% ratio width of the canine dental pulpa (Fig. 5) on CT-scan images (measures according to Knowlton and Whittemore) (Gipson et al., 2000; Kershaw et al., 2005; Linhart and Knowlton, 1976). Full adult dentition with permanent teeth (which in dogs of this size is about at the age of 25 weeks (Shabestari et al., 1967)) and the growth plate observations suggest that the dog's age at death was about 27 weeks.

Postcranial remains $(n=23)$ included 13 fragments of axial elements (vertebrae, ribs) and nine forelimb components. Twentyfive very small bone fragments could not be determined conclusively (recorded only as cf Canis) but were suggested as skull (8), vertebra (7), rib (5), or undetermined (5). Twenty-three of these specimens subsequently have been analyzed by Frido Welker, using the ZooMS method (van Doorn et al., 2011), together with other material not suspected to be dog.

Based on the smallest humeral diameter $(11.7 \mathrm{~mm})$, it was calculated with conversion formulae that the dog likely was about $0.45 \mathrm{~m}$ tall at the shoulder, weighing about $15 \mathrm{~kg}$ (Onar, 2005; Onar and Belli, 2005; Janssens et al., 2015, 2016a).

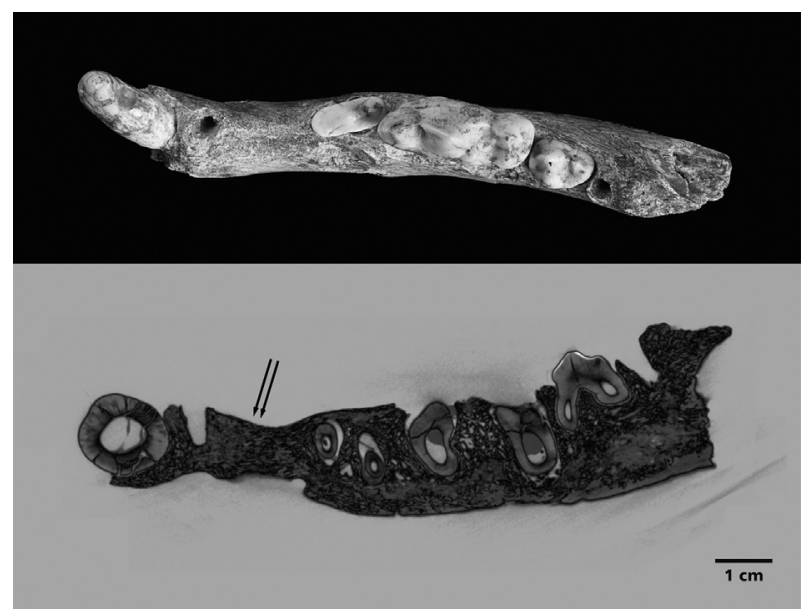

Fig. 5. Above: View of the Oberkassel dog mandible showing the occlusal aspect of the dentition. The $P_{1}$ and $M_{3}$ were lost due to taphonomic processes (alveoli can be recognized at left and right respectively) whereas the absence of $\mathrm{P}_{2}$ and $\mathrm{P}_{3}$ is congenital (no alveoli are present). P1 and M3 alveolar margins are rimmed; these are convincing evidence of periodontal disease. Photograph credited to Jürgen Vogel, Artwork credited to Martin Pütz, LVR-LandesMuseum Bonn. 


\subsection{Cranial and dental fragments}

Ten cranial specimens were identified as dog. Among them were seven loose teeth (right mandibular $\mathrm{I}_{1}, \mathrm{I}_{2}, \mathrm{I}_{3}$, left maxillary $\mathrm{P}^{1}$ and $\mathrm{P}^{3}$, left mandibular $\mathrm{P}_{2}$, and right maxillary $\mathrm{M}^{1}$ ). Three jaw fragments included one coronoid process and two rami with dentition. A small bone fragment of the right pre-maxilla included $\mathrm{I}^{2}$ and $\mathrm{I}^{3}$. A partial horizontal ramus of a right mandible (Fig. 4) held four teeth (C, $\mathrm{P}_{4}, \mathrm{M}_{1}$ (medio-distal diameter $26.5 \mathrm{~mm}$ ), and $\mathrm{M}_{2}$ ) in anatomical position.

A micro-CT scan $(100 \mu \mathrm{m}$ slices) was done for the entire mandible, demonstrating absent $\mathrm{P}_{2}$ and $\mathrm{P}_{3}$ (hypodontia, agenesis) (Fig. 5). Dental pathology included severe periodontal disease (Fig. 4) and enamel hypoplasia. There was no attrition. Abrasion was seen on the caudal side of the canine tooth (Fig. 4). Pathological features were classified following predetermined and reproducible criteria, and results were recorded by means of an established classification adapted for use on dry skulls (Janssens et al., 2016b; Verstraete et al., 1996a; Verstraete et al., 1996b).

The Oberkassel dog remains have been presented previously as one dog (Street, 2002), mainly due to lack of duplication of any skeletal components. However, more detailed examination of features of the loose right $\mathrm{M}^{1}$ (mesio-distal diameter $14.5 \mathrm{~mm}$ ) shows this specimen must in fact belong to a second smaller and older dog, based on difference in color, absence of red (hematite) staining, difference in attrition, and smaller size (Fig. 6).

To test the difference in size, we measured the mesio-distal diameter of the left maxillary $\mathrm{M}^{1}$ and right mandibular $\mathrm{M}_{1}$ in 25 skulls of recent mesaticephalic medium sized dogs from the collection that is curated at the Department of Morphology, Faculty of Veterinary Medicine, Ghent-University, Belgium (Table 1). We then performed a regression analysis using these data. The mean mesio-distal diameter $\mathrm{M}^{1}$ was $13.8 \mathrm{~mm}$ (12.2-15); that of $\mathrm{M}_{1}$ was $23.3 \mathrm{~mm}(19.8-25.9)$. The mean difference between $\mathrm{M}^{1}$ and $\mathrm{M}_{1}$ was $9.5 \mathrm{~mm}$, with maximal difference $11 \mathrm{~mm}$. The difference in length between the two first molars of the Oberkassel specimen was $12 \mathrm{~mm}, 8 \%$ higher than the maximum among 25 modern dogs, and $26 \%$ higher than the mean difference among the modern dogs. A linear regression model with left maxillary $\mathrm{M}^{1}$ as explanatory variable and right mandible $\mathrm{M}_{1}$ as response variable showed an intercept of 9.45 (S.E. = 3.54) and slope of 1.01 (S.E. $=0.26$; $t_{23}=3.97 ; p<0.0001 ;$ Fig. 7 ). The estimated mesio-distal diameter of the right mandible $\mathrm{M}_{1}$, based on the measured mesio-distal diameter of the left maxillary $\mathrm{M}^{1}(14.5 \mathrm{~mm})$, equaled $24.1 \mathrm{~mm}$, with a 95\% prediction interval ranging between $21.9 \mathrm{~mm}$ and $26.3 \mathrm{~mm}$. Since the observed mesio-distal diameter of the right mandibular $\mathrm{M}_{1}$ of $26.5 \mathrm{~mm}$ falls outside of this interval, the analysis statistically supports our suggestion that the loose left maxillary $\mathrm{M}^{1}$ tooth came from a different and smaller individual.

\subsection{Interpretation of dental pathology}

Dental pathology consists of attrition, abrasion, enamel changes, and periodontal disease. The dental terminology used here is that of the American College of Veterinary Dentistry, described in detail with illustrations at: https://www.avdc.org/Nomenclature/NomenIntro.html (last consulted September 2017). The pathology reported here relates to the remains of the young Bonn Oberkassel dog. Observed pathology consists of tooth loss and agenesis (Fig. 5),
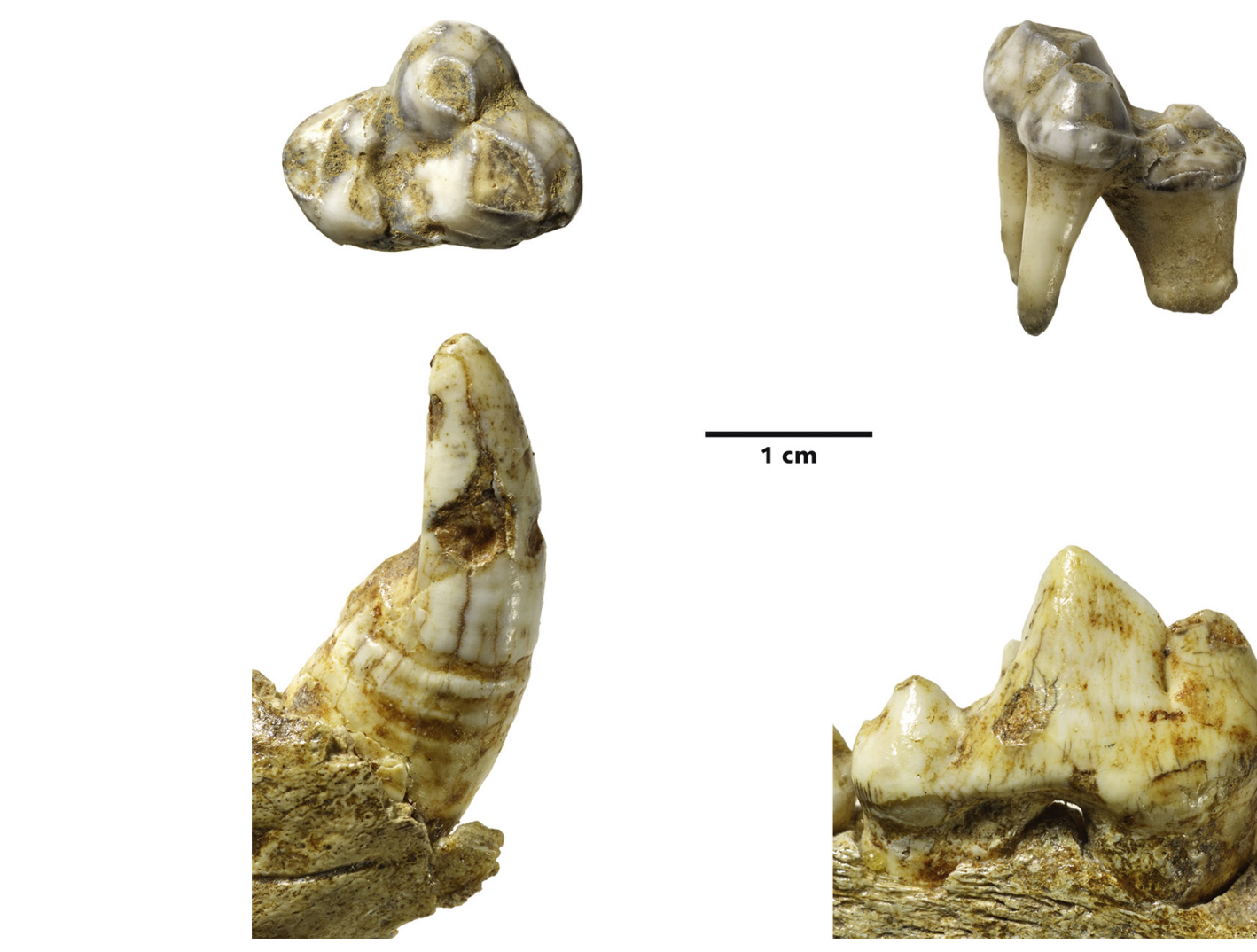

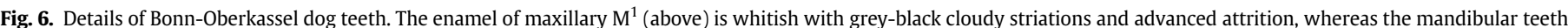

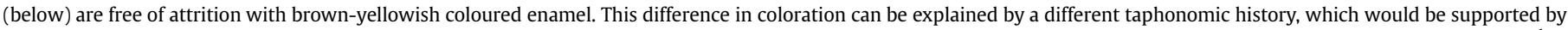

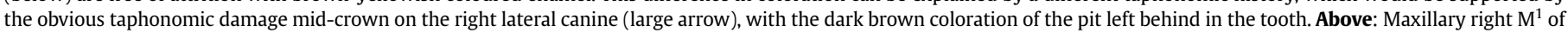

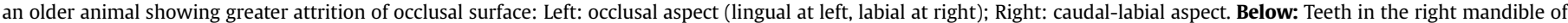

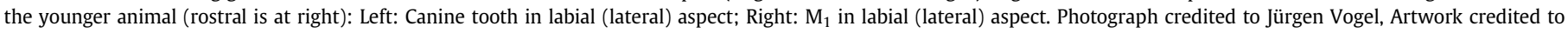
Martin Pütz, LVR-LandesMuseum Bonn. (For interpretation of the references to color in this figure legend, the reader is referred to the Web version of this article.) 
Table 1

Tooth mesio-distal diameter (in mm) of mandibular and maxillar M1 in recent dogs.

\begin{tabular}{|c|c|c|c|}
\hline \multirow[t]{2}{*}{ Accession number } & \multirow{2}{*}{$\frac{\text { mandible }}{\text { M1 left }}$} & \multirow{2}{*}{$\frac{\text { maxilla }}{\text { M1 right }}$} & \multirow[t]{2}{*}{ Breed } \\
\hline & & & \\
\hline 6714 & 19.8 & 12.2 & Beagle \\
\hline 6516 & 21.2 & 13.1 & Beagle \\
\hline $\mathrm{E}$ & 25.4 & 14.0 & Shepherd \\
\hline $\mathrm{D}$ & 22.6 & 14.4 & German shepherd \\
\hline 6756 & 23.4 & 13.7 & German shepherd \\
\hline 6734 & 23.5 & 13.7 & German shepherd \\
\hline 6608 & 25.9 & 14.9 & German shepherd \\
\hline 6734 & 23.3 & 13.7 & German shepherd \\
\hline 6641 & 22.8 & 13.7 & Braque \\
\hline 6664 & 23.5 & 13.9 & German wirehair \\
\hline 6753 & 23.5 & 14.1 & German wirehair \\
\hline 6612 & 22.4 & 12.8 & Schnauzer \\
\hline 6718 & 23.8 & 13.4 & Doberman Pinscher \\
\hline 6720 & 23.4 & 13.6 & Doberman Pinscher \\
\hline 6515 & 24.8 & 14.9 & Doberman Pinscher \\
\hline 6309 & 24.7 & 14.7 & Unknown \\
\hline 6514 & 24.8 & 14.9 & Belgian shepherd Groenendael \\
\hline 6509 & 24.1 & 14.4 & Belgian shepherd Malinois \\
\hline 6733 & 22.5 & 12.4 & Dalmatian \\
\hline 6639 & 23.0 & 13.2 & Cocker Spaniel \\
\hline 6743 & 23.0 & 14.2 & Siberian Husky \\
\hline 6691 & 22.3 & 14.6 & Riesenschnauzer \\
\hline 6617 & 24.3 & 14.1 & Labrador Retriever \\
\hline 6565 & 24.3 & 15.0 & Komondor \\
\hline 6611 & 24.1 & 12.4 & Labrador Retriever \\
\hline \multicolumn{4}{|l|}{ n 25} \\
\hline Minimum & 19.8 & 12.2 & difference $7.7 \mathrm{~mm}$ (6714) \\
\hline Maximum & 25.9 & 15.0 & difference 11 mm (6608) \\
\hline Mean & 23.3 & 13.8 & difference $9.5 \mathrm{~mm}$ \\
\hline Bonn-Oberkassel \# 2 & 26.5 & 14.5 & difference $12 \mathrm{~mm}$ \\
\hline
\end{tabular}

abrasion, periodontal disease, and enamel hypoplasia (Fig. 4).

Loss is taphonomic at rostral $\mathrm{P}_{4}$ and caudal $\mathrm{M}_{1}$.

Agenesis of $P_{2}, P_{3}$, in the right mandible is confirmed by absent teeth and underlying alveolar structures, indicating lack of tooth

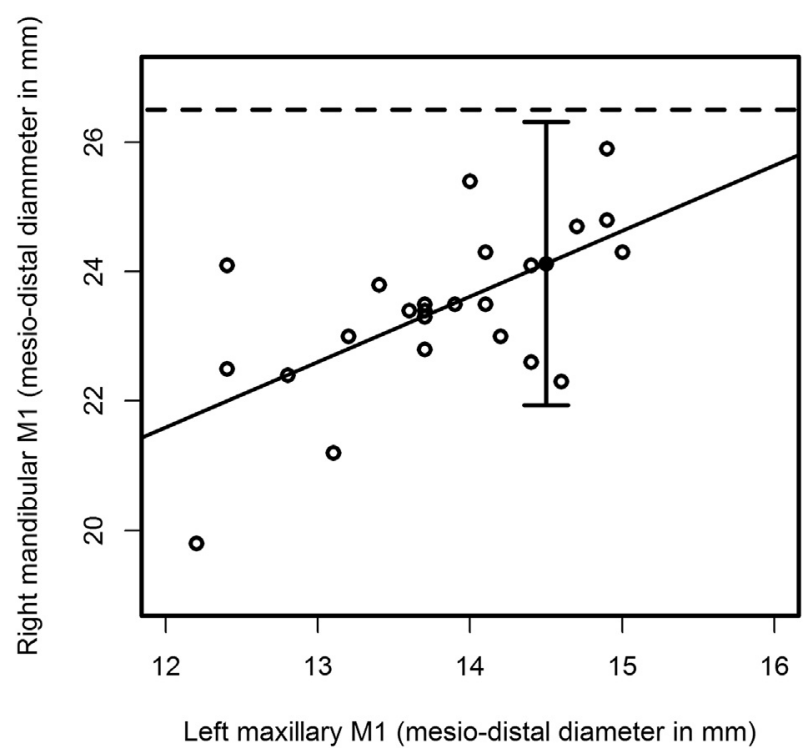

Fig. 7. Linear regression analysis of the mesio-distal diameter (in $\mathrm{mm}$ ) of the left maxillary and right mandibular first molar in 25 modern mesaticephalic, medium sized dogs. Observations are presented as open circles. The prediction of the mesiodistal diameter of the mandibular molar, based on the measure of the mesio-distal diameter of the single maxillary first molar $(14.5 \mathrm{~mm})$, is presented as a filled circle. The 95\% prediction interval is also shown (whiskers) and does not overlap with the dashed line corresponding to the observed mesio-distal diameter of the mandibular firs molar in the young dog specimen $(26.5 \mathrm{~mm})$. bud and bell development.

A minimal amount of attrition is present on $\mathrm{I}^{2}$.

Abrasion (Kreeger, 2003; Van Valkenburgh, 1988) at the caudal side of the mandibular canine tooth (cage biter syndrome in modern dogs) is caused by abrasive materials that are harder than the enamel (Zhang et al., 2014).

Bone loss at the alveolar rim (Fig. 4) is visible at $\mathrm{C}$ and on both roots of $\mathrm{P}_{4}$ and $\mathrm{M}_{1}$, as well as between the rostral and caudal root of $M_{1}$, with furcation being present. The area between both roots of $P_{4}$ also shows bone loss. The interdental area rostral and caudal from $\mathrm{M}_{1}$ is depressed due to bone loss. Some alveolar rims show a polished and rounded aspect typical of periodontal disease. Others (ie, around $\mathrm{C}$ ) reveal a sharp fragmented aspect typical for effects of taphonomic processes. Clearly, both processes contribute to bone loss at the alveolar rim. Foci revealing more polished bone loss include the rostral part of the rostral root of $\mathrm{P}_{4}$, the area between the roots of $\mathrm{P}_{4}$, the area between $\mathrm{P}_{4}$ and $\mathrm{M} 1$, the rostral part of the rostral root of $M_{1}$, and the area between $M_{1}$ and $M_{2}$. The area between $\mathrm{M}_{1}$ roots suggests periodontal disease with overlying taphonomic processes. There is bone loss with a polished aspect around the alveolar margin of $\mathrm{M}_{3}$ and $\mathrm{P}_{1}$, and at the caudal side of $\mathrm{M}_{2}$

Severe periodontal disease can be appreciated by $25-50 \%$ loss of the bone pocket and visible dental roots. Periodontal disease in such a young animal is totally unexpected (Miles and Grigson, 2003).

A visible and palpable horizontal enamel line (Fig. 8) is present in $\mathrm{C}, \mathrm{P}^{3}, \mathrm{P}_{4}$, and $\mathrm{M}_{1}$. On $\mathrm{C}$, it is the most dorsal broad line, $2 \mathrm{~mm}$ wide and fully circumferential. On $\mathrm{P}_{4}$, the line appears as pits and dots. On $\mathrm{P}^{3}$, the line is present at its caudal side. On $\mathrm{M}_{1}$, it is seen as a line bending slightly ventral rostrally and covering most of the crown. The line is clear on $\mathrm{M}_{1}$ and $\mathrm{C}$. Two other parallel enamel hypoplasia lines are seen below the dorsal line on C; these are less deep. This enamel hypoplasia can be related to the age that underlying pathogenic etiology occurred (Fig. 9). We suggest than an infection occurred at 19 weeks of age for the upper line and 21 and 23 weeks of age for the other lines.

Apart from pathological lesions, several examples of pseudopathology also are present (Fig. 10). The most important are tooth crown enamel cracks and fissures (mostly vertical), enamel discoloration (brown, yellow, black), fractures, and enamel sequesters. On roots, dentine pits, surface irregularities, discolorations, and cracks can be seen. Some of these lesions are present in every tooth in the specimen. Frequently, such features are taphonomic in origin.

\section{Discussion}

The general consensus is that the dog was buried together with two humans (Street and Joris, 2015). Several factors support this contention: (a) The small archaeological area (3 m diameter, one layer) in which all three were found covered with large $20 \mathrm{~cm}$ thick basalt blocks and sprayed abundantly with red hematite powder, a substance foreign to the area and not discovered anywhere else in the mine (Feine et al., 2015); (b) the 14C dates statistically overlap; (c) no other human or canine remains were discovered in the larger area. Finally, it is improbable that these three corpses would have been buried separately over a long period of time, either deliberately or by accident.

The humans buried with the dog are $\mathrm{a}+-40$ year old man and a - +-25 year old parous woman. Both fall within the normal stature variance of Late Palaeolithic hunter-gatherers. The man had two traumatic lesions. One is a healed oblique distal ulnar fracture of the right arm. The other is a right coro-claviculur ossification (Trinkhaus, 2015; 122-123). He also had moderate-to-advanced periodontal disease with considerable maxillary tooth loss, severe 


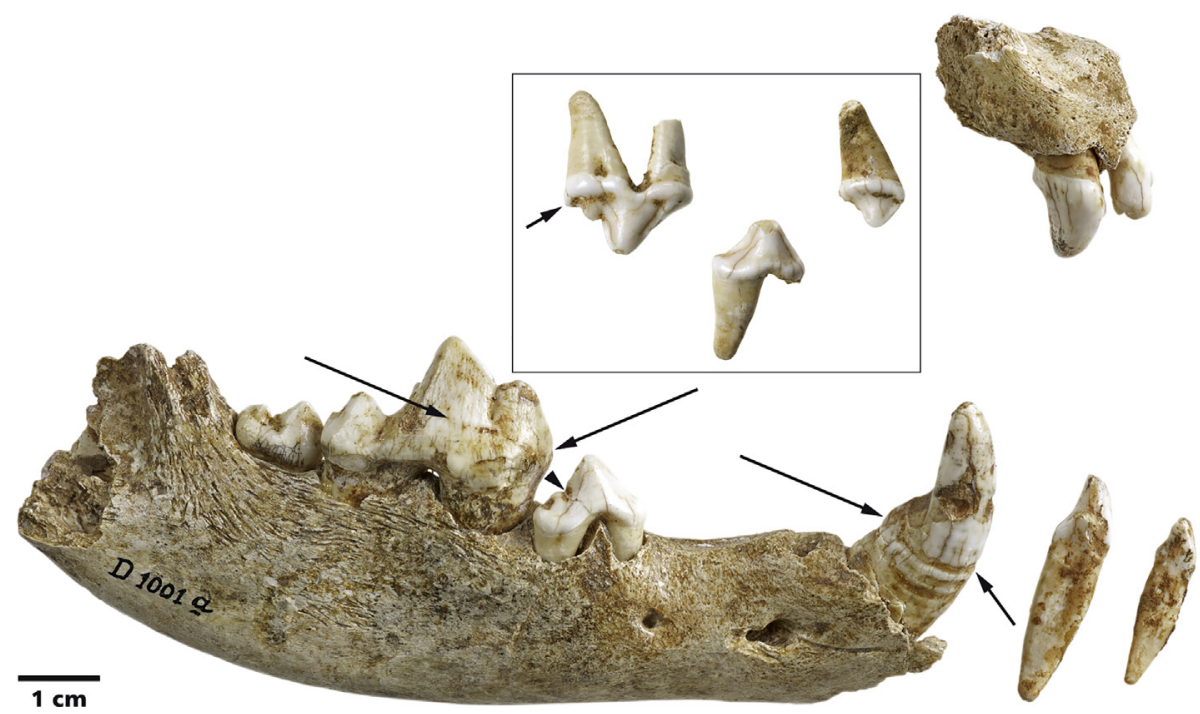

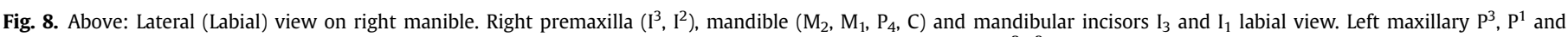

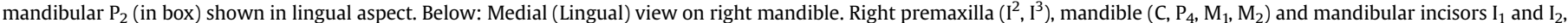

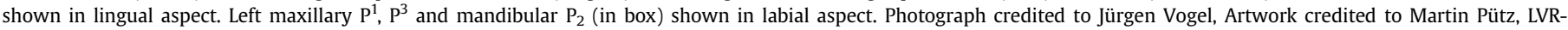
LandesMuseum Bonn.

tooth abrasion, and a dental alveolar lesion. The woman had moderate periodontal disease, dental calculus, and a dental alveolar lesion. These are features of significant oral cavity disease (Lacy, 2015). The oral condition of these two genetically very close individuals (Mittnik and Krause, 2015) seems to have been common among Late Paleolithic humans (Lacy, 2015). Several grave goods accompanied the burial, including a bone pin, a flat elk-antler sculpture of a large ungulate head (most likely an elk), a modified os penis (baculum) of a bear, and a modified red deer incisor (Giemsch et al., 2015). We add to this grave goods list the tooth from the second dog.

We cannot know if the dog was killed advisedly to be buried together with the humans or if it accidently died spontaneously, as a consequence of its previous illnesses, or due to other reasons, and contemporaneously with the humans. Killing of dogs to accompany human burials is not unusual in archaeological settings, and may represent a ritual or religious behavior, perhaps related to a belief in afterlife (Gräslund, 2004; Larsson, 1990; Losey et al., 2014; Morey, 2010; Müller, 2005; Pionnier-Capitan, 2010).

Dog burials occur frequently later in time, starting in the Near Eastern Neolithic Natufian period, about 11,600 years ago (Clutton-

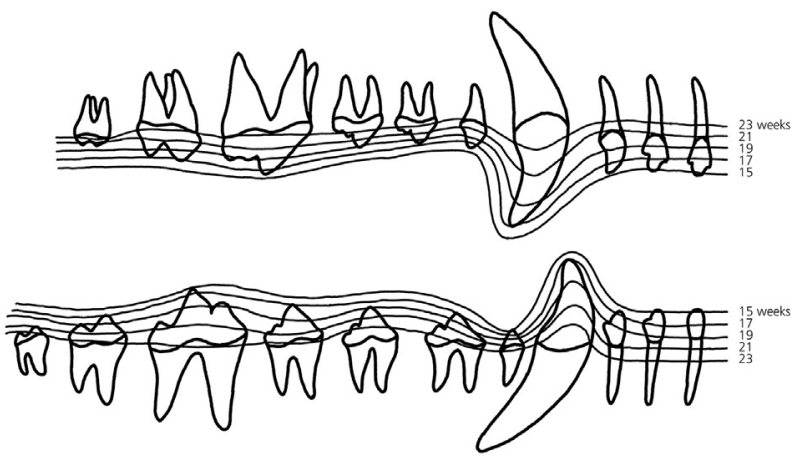

Fig. 9. Schematic representation of horizontal enamel hypoplasia lines caused by a Morbilli virus infection in dogs, in relation to their age in weeks at the onset of infection. The line seen in the younger Bonn-Oberkassel dog indicates 19 weeks of age. Permission of F. Verstraete, University of Davies, California, USA. Artwork credited to Martin Pütz, LVR-LandesMuseum Bonn.
Brock, 2012; 20-22). Important dog burials in more recent periods include those at the Koster site in Illinois and in Mesolithic Scandinavia, about 8500 to 6500 years ago (Morey, 2010). Massive dog burials took place in Ashkelon (Israel) with 1200 dogs buried about 2500 years ago (Wapnish and Hesse, 1993) during the Bronze Age (Morey, 2010; 153). For an overview on dog burials see Morey (2006).

These two late Pleistocene Bonn-Oberkassel dogs provide some of the oldest undisputed evidence for domestic dogs. While the younger dog has been dated and DNA study has confirmed its status as a dog, comparable exams on the single tooth remain in progress. Since the latter is part of the burial, it must have pre-dated the younger dog by a presently-unknown time period.

These Magdalenian dogs (Table 2) cluster in a group that is aged

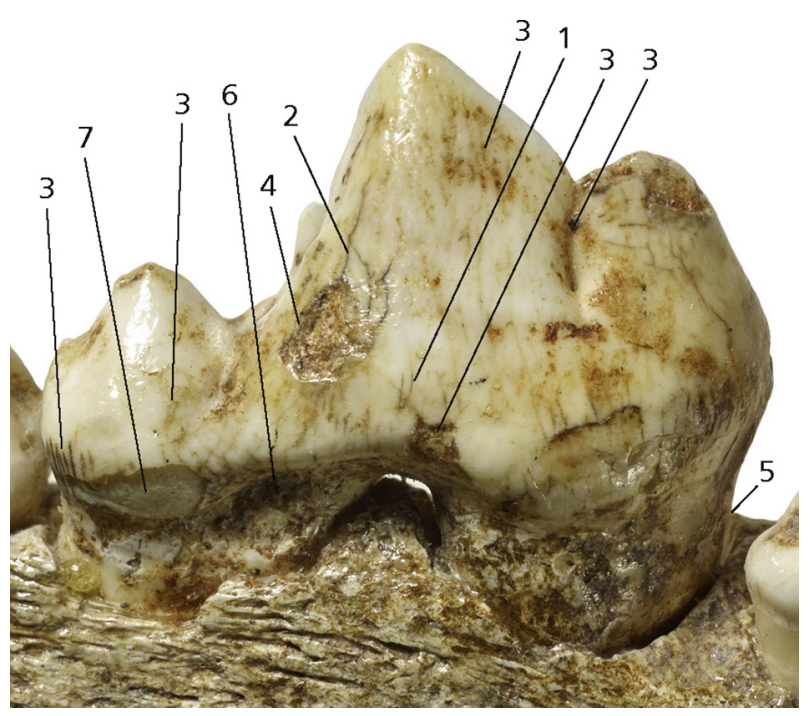

Fig. 10. Taphonomic processes in M1. Crown: enamel cracks (1) and fissures (2) (most vertical), enamel discoloration (3) (brown, yellow, black), enamel sequesters and chip fractures (4). Root: dentine pits and surface irregularities (5), discoloration (6) and dentine sequesters (7). Photograph credited to Jürgen Vogel, Artwork credited to Martin Pütz, LVR-LandesMuseum Bonn. 
Table 2

Pleistocene dogs, location and approximate dating.

\begin{tabular}{|c|c|c|c|}
\hline Specimen & Country & Publication & Approximate dating (cal BC) \\
\hline \multicolumn{4}{|l|}{ indirect dating in italics } \\
\hline Eralla & Spain & Altuna et al., 1984 & $17000-12500 ?$ \\
\hline Bonn-Oberkassel & Germany & this article & 12200 \\
\hline Monruz & Switzerland & Leesch et al., 2012 & 13500 \\
\hline Kesserloch & Switzerland & Napierala and Uerpmann, 2010 & 12350 \\
\hline Hauterive-Champréveyres & Switzerland & Morel et al., 1997 & 13500 \\
\hline Montespan & France & Pionnier-Capitan et al., 2011 & 12500 \\
\hline Le Closeau & France & Pionnier-Capitan et al., 2011 & 12000 \\
\hline Le Morin & France & Boudadi-Maligne et al., 2012 & 12600 \\
\hline Bonn-Oberkassel new specimen & Germany & This article & $?$ \\
\hline
\end{tabular}

from around 14.5-15 kya cal BP, from Spain: Eralla (Altuna et al., 1984); Switzerland: Kesserloch, Hauterive-Champréveyres, and Monruz (Leesch et al., 2012; Morel et al., 1997; Napierala and Uerpmann, 2012); France: Montespan, Le Closeau, Le Morin, Pont d'Ambon and Saint Thibaud de Couze (Boudadi-Maligne et al., 2012; Célérier, 1994; Célérier et al., 1999; Pionnier-Capitan et al., 2011); and Germany (Verworn et al., 1919; Street et al., 2015).

The dating of this dog grouping falls at the beginning of a long period of rapid climatic and environmental change (Greenland Interstadial 1- GI1) during which the open mammoth steppe biotope of the Late Pleistocene gave way to more wooded conditions and ultimate replacement by the fully forested conditions of the mid-Holocene (Street and Joris, 2015). The existence of this type of environment was corroborated by stable isotope studies of both humans (Nehlich and Richards, 2015: 211).

The increasingly closed-in environment may have been an influential factor for using dogs in hunting, enabling late glacial hunter-gatherers to benefit from the superior auditory and olfactory abilities of canids (; Hepper and Wells, 2005a,b; Romanes, 1887). Wolves and dogs have 200 million olfactory neurons (humans have about 5 million). Dogs smell 100-10000 times better than humans (Moulton, 1977), hear noises up to $80 \mathrm{kHz}$ (humans detect up to $20 \mathrm{kHz}$ ), and detect low decibel infra-sounds kilometers away (Asa and Mech, 1995; Lipman and Grassi, 1942). Hunting assistance may provide a fundamental and logical motivation for our understanding of the desire to possess dogs Genetic studies (Botigué et al., 2016; Pang et al., 2009; Savolainen et al., 2002) suggest that domestication of wolves may have occurred as early as about 39000 years ago in East Asia. In the latter scenario, these Magdalenian dogs could represent a Northwest spread from a surviving dog founder group, after the Last Glacial Maximum.

We have certain reservations about some reasons that have been proposed to explain wolf domestication. Herding or guarding domestic animals, and pest control around harvested food supplies, could not apply to pre-Neolithic societies where no grain storage was present. Further, rats and mice are not known to have been present in Western Europe before the Bronze Age (Cucchi et al., 2005; Donaldson, 1915). On the other hand, a role for dogs in guarding dwellings or settlements may have been beneficial during the Magdalenian because large predators such as brown bears repopulated the European landscape from southern refugia (Bocherens et al., 2011; Hewitt, 1999; Pacher and Stuart, 2009; Stewart et al., 2010; Tesson, 2013; Tetzlaff et al., 2007).

Evidence for at least seasonally stable human settlements of hunter-gatherers suggest that waste disposal by dogs may have been an incidental aspect of their presence. However, the specific time period of the burials that we discuss here does not suggest local stable seasonal occupations. Further, no bone remains with dog gnawing marks have been identified from the time period (Street et al., 1994).
Other motivations for dog keeping and breeding, such as canophagy or for pelts, are highly improbable as primary factors in wolf domestication. Dogs are extremely rare in the Palaeolithic (AarisSørensen, 2004; Pionnier-Capitan, 2010; Rütimeyer, 1861; Street, 1989, 1991) and cannot have been an important source of food and pelts. Cut marks on Palaeolithic dog bones as direct evidence for their consumption are just as rare (Boudadi-Maligne et al., 2012; Boudadi-Maligne and Escarguel, 2014; Harcourt, 1974; Manwell and Baker, 1984; Pionnier-Capitan, 2010) and at most suggest occasional skinning and opportunistic de-fleshing. Use of dogs for assistance in warfare is unsupported by dog remains documenting severe trauma, which would be expected in battle-associated dog remains. The disappearance of Neanderthals cannot be attributed to dog-assisted Homo sapiens-induced extinction. No dog remains are known from the final stage of the Middle Palaeolithic, the Châtelperronian, or the initial Aurignacian, the period and contexts during which Homo sapiens and Neanderthals may have co-existed. Further, the demise of Neanderthals increasingly is proposed to fall within a context of "make love not war" (Fu et al., 2015; Herrera et al., 2009; Kuhlwilm et al., 2016; Lowery et al., 2013).

The pathology observed in the young Bonn-Oberkassel dog allows several tentative conclusions to be drawn. The animal may have suffered from a morbillivirus infection at the age around age 19 weeks, and accordingly developed horizontal enamel hypoplasia of $C, \mathrm{P}^{3}, \mathrm{P}_{4}$, and $\mathrm{M}_{1}$. Agenesis of $\mathrm{P}_{2}$ and $\mathrm{P}_{3}$ also could be explained by morbillivirus infection, as the virus can necrotize tooth germs (Beineke et al., 2009; Dubielzig, 1979). Other possible differential diagnoses of observed dental pathology include genetic disease (e.g. mutations of MSX1, PAX9, AXIN2 genes) (Nieminen, 2009), trauma (Obersztyn, 1963), bacterial infection (Morningstar, 1937), and toxicological events (such as local environmental arsenic) (Özmeriç, 2002). On the other hand, genetic reasons for hypodontia relate most frequently to P1 and M3 (Andersone and Ozolins, 2000; Dolgov and Rossolimo, 1964; Janssens et al., 2016b; Losey et al., 2014; Vigne, 2011). Additionally, other known genetic mutations involving teeth are found in inbred modern dog breeds. Finally, toxicological reasons are quite improbable during the Late Paleolithic, since the sources for these events largely are modern as well.

Abrasion of $\mathrm{C}$ is difficult to explain in a pre-metallurgical context, since gnawing on bones does not cause such a lesion: Crystalline hydroxyapatite in bones is three times softer that than enamel (Habelitz et al., 2001; Mahoney et al., 2004). Also, if misalignment were present, one would expect a wear facet on the caudo-distal side of $\mathrm{I}^{3}$, but no such lesion is present. Another possibility might be that the lesion is an eroded enamel hypoplasia focus with locally-deficient enamel quality. Lastly, this lesion could be caused by stone chewing (pica), a behavioral phenomenon observed in some modern dogs with compulsive disorders, boredom, or the chronic encephalitis stage of morbillivirus infection (canine distemper). A difficulty is that this abrasion feature 


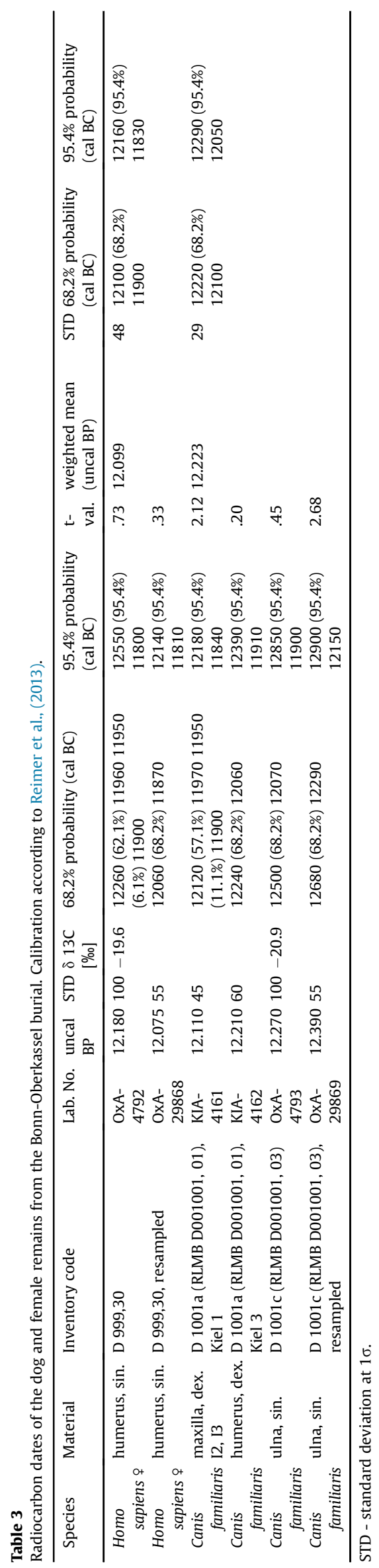

also can be observed in ancient and modern dogs without evidence of morbillivirus infection. Thus, cautious interpretation is indicated.

While taphonomic processes are theoretically possible sources of alveolar margin pseudopathology, it is clear that very significant periodontal disease was present in the specimen that we evaluated. Such severe periodontal disease in a puppy seems incongruous; it is expected in older dogs and wolves (Albuquerque et al., 2012; Janssens et al., 2016b; Miles and Grigson, 2003; Pavlica et al., 2008; Watson, 1994). It could however be explained by immune deficiency, a disease that can cause aggressive juvenile periodontitis (Bimstein et al., 2005; Nibali, 2015) and canine morbillivirus infection is not unexpected in immune-deficient dogs (Beineke et al., 2009; Deem et al., 2000).

While a horizontal enamel hypoplasia line is very suggestive of morbillivirus infection in dogs (Bittegeko et al., 1995; May et al., 1994; Vandevelde et al., 1980), it is known that humans, apes, pigs, and seals, may develop a similar lesion from various viral and bacterial infections, malnutrition, and stress (Bittegeko et al., 1995; Dobney and Ervynck, 2000; Guatelli-Steinberg et al., 2004; Kreshover, 1944; Lukacs, 1999).

Definitive diagnosis of morbillivirus infection is done in clinical practice by extracting the virus or viral RNA (short half life) from soft tissues (Frisk et al., 1999), or by detecting histopathologic inclusion bodies (Loots et al., 2017) in brain, skin, spleen, liver, and other tissues, but not in bone. Thus, usual diagnostic methods for morbillivirus cannot be used with archaeological specimens (Haines et al., 1999; Loots et al., 2017).

Other rare reasons have been reported to cause enamel hypoplasia in dogs, including zinc deficiency in a litter of Pharaoh Dogs (Campbell and Crow, 2010); hereditary enamel hypoplasia in Swedish standard poodles (Mannerfelt and Lindgren, 2009); and recessive mutation of the ENAM gene in Italian greyhounds (Gandolfi et al., 2013). These events are most improbable Oberkassel specimen because they appear to be consequences of modern dog breeding practices.

Still other reasons could explain the horizontal enamel hypoplasia line. Potential taphonomic causes include acid water etching, erosive strangulation by plant roots, and action of rock or sand grains in eroding surfaces. No such enamel lesions were found on any of the human teeth. The corpses' micro-environment is considered to have been quite protective, explaining the good preservation of bones and teeth (Feine et al., 2015). While morbillivirus infection cannot be presented as a definitive diagnosis, it should remain high on the list of potential differential diagnoses.

Morbillivirus is endemic in the wild and mainly pathogenic and highly lethal in Canidae. The disease has three phases, over about three weeks' time. Clinical signs first appear three to four days after infection, and include high fever, anorexia, dehydration, lethargy, diarrhea, and vomiting (Martella et al., 2008). During the second week, primary clinical signs include rhinitis, laryngitis, tracheitis, and pneumonia, along with continued first week signs. Most dogs (80-90\%) die during this period. Neurologic clinical signs seen from week three are many, including pica and seizures. A good indicator of high lethality in a wild non-vaccinated adult population $(n=544)$ of dogs and wolves (Losey et al., 2014) was absence of horizontal enamel hypoplasia (all infected puppies must have died).

The oral lesions in the Bonn-Oberkassel dog remains are exceptional. The dog was buried at the age of at least 28 weeks, following multiple episodes of severe illness between 19 and 23 weeks of age. The possibility of surviving a morbillivirus infection as a wild immune-depressed dog is extremely low. The two succeeding severe bouts of disease make the probability of surviving on its own almost non-existent.

We hypothesize that the dog could have survived only with long 
lasting and intensive human care. This would have consisted of keeping the dog warm and clean (diarrhea, urine, vomit, saliva), certainly giving water and possibly food. During active disease, the puppy was clearly too sick to be of any practical use to humans; there was no materialistic benefit. Quite the opposite, the benefit conferred was reversed, with the humans being useful to the dog. This suggests the possible existence of a unique human-canine bond.

\section{Conclusion}

The Bonn-Oberkassel dog remains are attributed to a late Palaeolithic double human burial dated to 14200 years ago. They are identified as representing two animals, one of them a mature dog from which only a maxillary $\mathrm{M}^{1}$ remained and the other represented by skull and post-cranial skeletal elements of a dog aged at least 28 weeks. We hypothesize that this dog had been extremely sick (between 19 and 23 weeks old) during a six weeks or longer period prior to its death. This hypothesis is based on the observed dental pathology that shows signatures of enamel hypoplasia, severe periodontal disease, and atypical abrasion in C. We hypothesize that this group of observations was caused by immune deficiency related to canine morbillivirus infection.

There are multiple differential diagnostic considerations at several levels, including effects of decomposition (personal communication D.F. Lawler) and taphonomic influences. We believe that canine morbillivirus infection is consistent with the pathologies that we observed. We hypothesize that this puppy could have survived only with intensive human care over several weeks. The dog was young and sick, likely was untrained as a result, and thus had no obvious utilitarian value to surrounding humans. Thus, we hypothesize further that the inferred supportive care probably was due to compassion or empathy, without any expectation of reciprocal utilitarian benefits. We suggest that the BonnOberkassel dog provides the earliest known evidence for a purely emotion-driven human-dog interaction.

\section{Conflicts of interest}

There are no conflicts of interest.

\section{Funding sources}

This research did not receive any specific grant from funding agencies in the public, commercial, or non-profit sectors.

\section{Acknowledgements}

Frank Verstraete and Leen Verhaert are both thanked for helping with detailed dental diagnostics. The four reviewers are thanked for their time and effort. The article has benefitted extensively from their corrections, suggestions and opinions. Denis Lawler is thanked specifically for intensively helping with several aspects of the writing mainly on diagnostics and discussion. Martin Pütz and JürgenVogel are both thanked for helping with pictures and figures.

\section{References}

Aaris-Sørensen, K., 2004. Med Hunden i Fokus en metod att identifiera hundars användningsområde utifrån det postkraniala skelettet. Vidensk Medd fra Dansk naturh Foren Lund Institutionen för arkeologi och antikens historia 140, $129-146$.

Albuquerque, C., Morinha, F., Requicha, J., Martins, T., Dias, I., Guedes-Pinto, H., Bastos, E., Viegas, C., 2012. Canine periodontitis: the dog as an important model for periodontal studies. Vet. J. 191, 299-305.

Altuna, J., Baldeon, A., Mariezkurrena, K., 1984. Dépôts rituels magdaléniens de la grotte d' Erralla (Pays Basque). Munibe 36, 3-10.
Andersone, Z., Ozolins, J., 2000. Craniometrical characteristics and dental anomalies in wolves Canis lupus from Latvia. Theriol 45, 549-558.

Asa, C.S., Mech, L.D., 1995. A review of the sensory organs in wolves and their importance to life history. In: Carbyn, L., Fritts, S., Seip, D. (Eds.), Occasional Publication of the Canadian Circumpolar Institute. Canadian Circumpolar Institute Publications. University of Alberta, pp. 287-291.

Beineke, A., Puff, C., Seehusen, F., Baumgärtner, W., 2009. Pathogenesis and immunopathology of systemic and nervous canine distemper. Vet. Immunol. Immunopathol. 127, 1-18.

Benecke, N., 1987. Studies on early dog remains from Northern Europe. J. Archaeol. Sci. 14, 31-49.

Bicho, N., 2013. Humans's best friends - dogs... And fire! Pleistocene foragers on the iberian peninsula:their culture and environment. Festschrift in honour of GerdChristian Weniger for his sixtieth Birthday. In: Pastoors, A., Aufferman, B. (Eds.), Wissenschaeftliche schriften des Neanderthal museums, Neanderthal. Metmann press, pp. 217-242.

Bimstein, E., Mcllwain, M., Katz, J., Jerrell, G., Primosch, R., 2005. Aggressive periodontitis of the primary dentition associated with idiopathic immune deficiency: case report and treatment considerations. J. Clin. Pediatr. Dent 29, 27-31.

Bittegeko, S., Arnbjerg, J., Nkya, R., Tevik, A., 1995. Multiple dental developmental abnormalities following canine distemper infection. J. Am. Anim. Hosp. Assoc. 31, 42-45.

Bocherens, H., Stiller, M., Hobson, K., Pacher, M., Rabeder, G., Burns, J., Tuetken, T. Hofreiter, Mi, 2011. Niche partitioning between two sympatric genetically distinct cave bears (Ursus spelaeus and Ursus ingressus) and brown bear (Ursus arctos) from Austria: isotopic evidence from fossil bones. Quat. Int. 245, $238-248$.

Botigué, L., Song, S., Scheu, A., Gopalan, S., Pendleton, A., Oetjens, M., Taravella, A., Seregély, T., Zeeb-Lanz, A., Arbogast, R., Bobo, D., Daly, K., Unterländer, M. Burger, J., Kidd, J., Veeramah, K., 2016. Ancient European Dog Genomes Reveal Continuity since the Early Neolithic. https://doi.org/10.1101/068189.

Boudadi-Maligne, M., Mallye, J., Langlais, M., Barshay-Szmidt, C., 2012. Des restes de chiens magdaléniens à l'abri du Morin (Gironde, France). Implications socioéconomiques d'une innovation zootechnique. Revue d'archéologie préhistorique $23,39-54$.

Boudadi-Maligne, M., Escarguel, G., 2014. A biometric re-evaluation of recent claims for Early Upper Palaeolithic wolf domestication in Eurasia. J. Archaeol. Sci. 45, 80-89.

Camarós, E., Münzel, S.C., Cueto, M., Rivals, F., Conard, N.J., 2016. The evolution of Paleolithic hominin-carnivore interaction written in teeth: stories from the Swabian Jura (Germany). J. Archaeol. Sci. Rep. 6, 798-809.

Campbell, G.A., Crow, D., 2010. Severe zinc responsive dermatosis in a litter of Pharaoh Hounds. J. Vet. Diagn. Invest. 22, 663-666.

Célérier, G., 1994. L'abri sous roche de Pont d'Ambon à Bourdeilles (Dordogne): présentation. Gall. Prehist. 36, 65-65.

Célérier, G., Tisnerat, N., Valladas, H., 1999. Données nouvelles sur l'âge des vestiges de chien à Pont d'Ambon, Bourdeilles (Dordogne, France). Paléo 11, 163-165.

Clutton-Brock, J., 1995. Origins of the dog: domestication and early history. In: Serpell, J. (Ed.), The Domestic Dog: its Evolution, Behaviour and Interactions with People. Cambridge University Press, Cambridge, pp. 7-20.

Clutton-Brock, J., 2012. Animals as Domesticates. Michigan State University Press, East Lansing.

Crabtree, P.J., Campana, D.V., 1987. A new model for the domestication of the dog. Masca Research Papers in Science and Archaeology 4, 98-102.

Crockford, S.J., 2006. Rhythms of Life: Thyroid Hormone \& the Origin of Species: a 21st Century Way of Thinking about Domestication, Evolution \& Human Health that Goes beyond Genes. Trafford Publishing, Victoria.

Crockford, S.J., Kuzmin, Y.V., 2012. Comments on Germonpré et al., Journal of Archaeological Science 36, 2009 "Fossil dogs and wolves from Palaeolithic sites in Belgium, the Ukraine and Russia: osteometry, ancient DNA and stable isotopes", and Germonpré, Lázkičková-Galetová, and Sablin, Journal of Archaeological Science 39, 2012 "Palaeolithic dog skulls at the Gravettian Předmostí site, the Czech Republic". J. Archaeol. Sci. 39, 2797-2801.

Cucchi, T., Vigne, J., Auffray, J., 2005. First occurrence of the house mouse (Mus musculus domesticus Schwarz \& Schwarz, 1943) in the Western Mediterranean: a zooarchaeological revision of subfossil occurrences. Biol. J. Linn. Soc. 84 429-445.

Dayan, T., 1994. Early domesticated dogs of the Near East. J. Archaeol. Sci. 21, 633-640.

Deem, S.L., Spelman, L., Yates, R., Montali, R., 2000. Canine distemper in terrestria carnivores: a review. J. Zoo Wildl. Med. 31, 441-451.

Degerbřl, M., 1961. Der Hund, das älteste Haustier Dänemarks. Z. für Tierzuechtung Zuechtungsbiol. 76, 334-341.

Derr, M., 2011. How the Dog Became the Dog: from Wolves to Our Best Friends. Penguin, London.

Dobney, K., Ervynck, A., 2000. Interpreting developmental stress in archaeological pigs: the chronology of linear enamel hypoplasia. J. Archaeol. Sci. 27, 597-607.

Dolgov, V., Rossolimo, O., 1964. Dental abnormalities in Canis lupus. Acta Theriol. 8, $237-244$.

Donaldson, H.H., 1915. The Rat. Philadelpia University Press, Philadelphia, USA.

Drake, A.G., Coquerelle, M., Colombeau, G., 2015. 3D Morphometric Analysis of Fossil Canid Skulls Contradicts the Suggested Domestication of Dogs during the Late Paleolithic. Scientific reports 5. https://doi.org/10.1038/srep0829.

Driscoll, C.A., Macdonald, D., O'Brien, S., 2009. From wild animals to domestic pets, 
an evolutionary view of domestication. In: Proceedings of the National Academy of Sciences, vol. 106, pp. 9971-9978. Suppl. 1.

Druzhkova, A., Thalmann, O., Trifonov, V., Leonard, J., Vorobieva, N., Ovodov, N. Graphodatsky, A., Wayne, R., 2013. Ancient DNA analysis affirms the canid from Altai as a primitive dog. PLoS One 8 (3), e57754.

Dubielzig, R., 1979. The effect of canine distemper virus on the ameloblastic layer of the developing tooth. Vet. Parasitol. 16, 268-270.

Duleba, A., Skonieczna, K., Bogdanowicz, W., Malyarchuk, B., Grzybowski, T., 2015. Complete mitochondrial genome database and standardized classification system for Canis lupus familiaris. Forensic Sci. Int.: Genetics 19, 123-129.

Feine, S., Geimsch, L., Schmitz, R., 2015. The history of research and debate conderning the discovery of the Late Ice Age double burial of Oberkassel. In: Giemsch, L. Schmitz, R. (Eds.), The Late Glacial Burial from Oberkassel Revisited. Verlag Philipp von Zabern, pp. 1-18. Rheinische Ausgrabungen 72.

Frantz, L.A., Mullin, Victoria E., Pionnier-Capitan, M., Lebrasseur, O., Ollivier, M., Perri, A., Linderholm, A., Mattiangeli, V., Teasdale, M., Dimopoulos, E. Tresset, A., Duffraise, M., Mccormick, F., Bartosiewicz, L., Gal, E., Nyerges, E. Sablin, S., Bréhard, S., Mashkour, M., Bălăşescu, A., Gillet, B., Hughes, S., Chassaing, O., Hitte, C., Vigne, J.-D., Dobney, K., Hänni, C., Bradley, D., Larson, G. 2016. Genomic and archaeological evidence suggest a dual origin of domestic dogs. Science 352, 1228-1231.

Freedman, A.H., Gronau, I., Schweizer, R.M., Ortega-Del Vecchyo, D., Han, E. Silva, P.M., Galaverni, M., Fan, Z., Marx, P., Lorente-Galdos, B., 2014. Genome sequencing highlights the dynamic early history of dogs. PLoS Genet. 10, e1004016.

Frisk, A., König, M., Moritz, A., Baumgärtner, W., 1999. Detection of canine distemper virus nucleoprotein RNA by reverse transcription-PCR using serum, whole blood, and cerebrospinal fluid from dogs with distemper. J. Clin. Microbiol. 37 3634-3643.

Fu, Q., Hajdinjak, M., Moldovan, O., Constantin, S., Mallick, S., Skoglund, P. Patterson, N., Rohland, N., Lazaridis, I., Nickel, B., Viola, B., Prüfer, K., Meyer, M. Kelso, J., Reich, D., Pääbo, S., 2015. An early modern human from Romania with a recent Neanderthal ancestor. Nature 524, 216-219.

Gandolfi, B., Liu, H., Griffioen, L., Pedersen, N.C., 2013. Simple recessive mutation in ENAM is associated with amelogenesis imperfecta in Italian Greyhounds. Anim. Genet. 44, 569-578.

Gautier, A., 1998. De Gouden Kooi: over Het Ontstaan Van Het Huisdier. Belgium, Hadewych, Antwerp.

Germonpré, M., Sablin, M.V., Stevens, R.E., Hedges, R.E., Hofreiter, M., Stiller, M., Després, V.R., 2009. Fossil dogs and wolves from Palaeolithic sites in Belgium, the Ukraine and Russia: osteometry, ancient DNA and stable isotopes. J. Archaeol. Sci. 36, 473-490.

Germonpré, M., Lázničková-Galetová, M., Sablin, M.V., 2012. Palaeolithic dog skulls at the Gravettian Předmostí site, the Czech Republic. J. Archaeol. Sci. 39, 184-202.

Germonpré, M., Lázničková-Galetová, M., Losey, R.J., Räikkönen, J., Sablin, M.V. 2015. Large canids at the Gravettian Předmostí site, the Czech Republic: the mandible. Quat. Int. 359, 261-279.

Germonpré, M., Fedorov, S., Danilov, P., Galeta, P., Jimenez, E.-L., Sablin, M. Losey, R.J., 2017. Palaeolithic and prehistoric dogs and Pleistocene wolves from Yakutia: identification of isolated skulls. J. Archaeol. Sci. 78, 1-19.

Gräslund, A.-S., 2004. Dogs in Graves-a Question of Symbolism, Pecus. Man and Animal in Antiquity. The Swedish Institute in Rome, Rome, pp. 167-176.

Giemsch, L., Tinnes, J., Schmitz, R., 2015. Comparative studies of the art objects and other grave goods from Bonn-Oberkassel. In: Giemsch, L., Schmitz, R. (Eds.), The Late Glacial Burial from Oberkassel Revisited. Verlag Philipp von Zabern, pp. 231-251. Rheinische Ausgrabungen 72.

Gipson, P., Ballard, W., Nowak, R., Mech, D., 2000. Accuracy and precision of estimating age of gray wolves by tooth wear. J. Wildl. Manag. 64, 752-758.

Grimm, D., 2015. Dawn of the dog. Science 348, 274-279.

Guatelli-Steinberg, D., Larsen, C., Hutchinson, D., 2004. Prevalence and the duration of linear enamel hypoplasia: a comparative study of Neandertals and Inuit foragers. J. Hum. Evol. 47, 65-84.

Habelitz, S., Marshall, S., Marshall, G., Balooch, M., 2001. Mechanical properties of human dental enamel on the nanometre scale. Arch. Oral Biol. 46, 173-183.

Haines, D.M., Martin, K.M., Chelack, B.J., Sargent, R.A., Outerbridge, C.A., Clark, E.G., 1999. Immunohistochemical detection of canine distemper virus in haired skin nasal mucosa, and footpad epithelium: a method for antemortem diagnosis of infection. J. Vet. Diagn. Invest. 11, 396-399.

Harcourt, R.A., 1974. The dog in prehistoric and early historic Britain. J. Archaeol. Sci. $1,151-175$.

Henke, W., Schmitz, R., Giemsch, L., 2006. Die spät Eiszeitlichen Funde von BonnOberkassel. In: Uelsberg, G., Lötters, S. (Eds.), Roots/Wurzeln der Menschheit, pp. 243-255.

Hepper, P.G., Wells, D.L., 2005a. How many footsteps do dogs need to determine the direction of an odour trail? Chem. Senses 30, 291-298.

Hepper, P.G., Wells, D.L., 2005b. Perinatal olfactory learning in the domestic dog. Chem. Senses 31, 207-212.

Herrera, K.J., Somarelli, J., Lowery, R., Herrera, R., 2009. To what extent did Neanderthals and modern humans interact? Biol. Rev. 84, 245-257.

Hewitt, G.M., 1999. Post-glacial re-colonization of European biota. Biol. J. Linn. Soc. 68, 87-112.

Higham, T., Schmitz, R., Giemsch, L., Feine, S., Street, M., 2015. Radiocarbon dating of the Oberkassel specimen. In: Giemsch, L., Schmitz, R. (Eds.), The Late Glacial Burial from Oberkassel Revisited. Verlag Philipp von Zabern, pp. 63-67.
Rheinische Ausgrabungen 72.

Horard-Herbin, M., Tresset, A., Vigne, J.-D., 2014. Domestication and uses of the dog in western Europe from the paleolithic to the iron age. Animal Frontiers 4, $23-31$.

Janssens, L., Napierala, H., Street, M., 2015. Pathology in the bonn-oberkassel dog. In: Giemsch, L, Schmitz, R. (Eds.), The Late Glacial Burial from Oberkassel Revisited. Verlag Philipp von Zabern, pp. 274-281. Rheinische Ausgrabungen 72.

Janssens, L., Street, M., Miller, R., Hazewinkel, H., Giemsch, L., Schmitz, R., 2016a. The oldest case yet reported of osteoarthritis in a dog: an archaeological and radiological evaluation. J. Small Anim. Pract. 57, 568-574.

Janssens, L., Verhaert, L., Berkowic, D., Adriaens, D., 2016b. A standardized framework for examination of oral lesions in wolf skulls (Carnivora: canidae: Canis lupus). J. Mammal. 97, 1111-1124.

Kershaw, K., Allen, L., Lisle, L., Withers, K., 2005. Determining the age of adult wild dogs (Canis lupus dingo, C.l. domesticus and their hybrids). I. Pulp cavity: tooth width ratios. Wildl. Res. 32, 581-585.

Kreeger, T.J., 2003. The internal wolf: physiology, pathology, and pharmacology. In: Mech, D., Boitani, L. (Eds.), Wolves: Behavior, Ecology and Conservation. University of Chicago Press, Chicago, pp. 192-217.

Kreshover, S.J., 1944. The pathogenesis of enamel hypoplasia: an experimental study. J. Dent. Res. 23, 231-238.

Kuhlwilm, M., Gronau, I., Hubisz, M., de Filippo, C., Prado-Martinez, J., Kircher, M. Fu, Q., Burbano, H., Lalueza-Fox, C., de la Rasilla, M., Antonio Rosas, A., Rudan, P., Brajkovic, D., Kucan, Z., Gušic, I., Marques-Bonet, T., Andrés, A., Viola, B., Pääbo, S., Meyer, M., Siepel, A., Castellano, S., 2016. Ancient gene flow from early modern humans into Eastern Neanderthals. Nature 530, 429-433.

Lacy, S., 2015. The dental metrics, morphology, and oral paleopathology of Oberkassel 1 and 2. In: Giemsch, L., Schmitz, R. (Eds.), The Late Glacial Burial from Oberkassel Revisited. Verlag Philipp von Zabern, pp. 133-150. Rheinische Ausgrabungen 72 .

Larson, G., Karlsson, E., Perri, A., Webster, M., Ho, S., Peters, J., Stahl, P., Piper, P., Lingaas, F., Fredholm, M., 2012. Rethinking dog domestication by integrating genetics, archeology, and biogeography. In: Proceedings of the National Academy of Sciences, vol. 109, pp. 8878-8883.

Larsson, L., 1990. Dogs in fraction-symbols in action. Contrib. Music Educ. 5, 153-160.

Leesch, D., Müller, W., Nielsen, E., Bullinger, J., 2012. The Magdalenian in Switzerland: re-colonization of a newly accessible landscape. Quat. Int. 272, 191-208.

Linhart, S., Knowlton, F., 1976. Determining age of coyotes by tooth cementum layers. J. Wildl. Manag. 31, 362-365.

Lipman, E., Grassi, J., 1942. Comparative auditory sensitivity of man and dog. Am. J. Psychol. 55, 84-89.

Loots, A.K., Mitchell, E., Dalton, D.L., Kotzé, A., Venter, E.H., 2017. Advances in canine distemper virus pathogenesis research: a wildlife perspective. J. Gen. Virol. 98, $311-321$.

Losey, R., Jessup, E., Nomokonova, T., Sablin, M., 2014. Craniomandibular trauma and tooth loss in northern dogs and wolves: implications for the archaeological study of dog husbandry and domestication. PLoS One 9 (6), e99746.

Lowery, R.K., Uribe, G., Jimenez, E., Weiss, M., Herrera, K., Regueiro, M., Herrera, R., 2013. Neanderthal and Denisova genetic affinities with contemporary humans: introgression versus common ancestral polymorphisms. Gene 530, 83-94.

Lukacs, J.R., 1999. Enamel hypoplasia in deciduous teeth of great apes: do differences in defect prevalence imply differential levels of physiological stress? Am. J. Phys. Anthropol. 110, 351-363.

Lupo, K.D., 2011. A Dog Is for Hunting. Oxbow books, Oxford.

Mannerfelt, T., Lindgren, I., 2009. Enamel defects in standard poodle dogs in Sweden. J. Vet. Dent. 26, 213-215.

Mahoney, E.K., Rohanizadeh, R., Ismail, F., Kilpatrick, N., Swain, M., 2004. Mechanical properties and microstructure of hypomineralised enamel of permanent teeth. Biomaterials 25, 5091-5100.

Manwell, C., Baker, C., 1984. Domestication of the dog: hunter, food, bed-warmer, or emotional object? Z. für Tierzuechtung Zuechtungsbiol. 101, 241-256.

Martella, V., Elia, G., Buonavoglia, C., 2008. Canine distemper virus. Vet. Clin. Small Anim. Pract. 38, 787-797.

May, C., Carter, S., Bell, S., Bennett, D., 1994. Immune responses to canine distemper virus in joint diseases of dogs. Rheumatology 33, 27-31.

Miles, A., Grigson, C., 2003. Colyer's Variations and Diseases of the Teeth of Animals. Cambridge University Press, Cambridge.

Miller, R., 2012. Mapping the expansion of the northwest magdalenian. Quat. Int. $272-273,209-230$

Mittnik, A., Krause, J., 2015. The Oberkassel double burial from a genetic perspective. In: Giemsch, L., Schmitz, R. (Eds.), The Late Glacial Burial from Oberkassel Revisited. Verlag Philipp von Zabern, pp. 223-230. Rheinische Ausgrabungen 72.

Mivart, S., 1890. Dogs, Jackals, Wolves, and Foxes: a Monograph of the Canidae. With Woodcuts, and 45 Coloured Plates Drawn from Nature by JG Keulemans and Hand-coloured. RH Porter, London.

Morel, P., Müller, W., Leesch, D., Burke, A., Chaline, J., Müller, W., Chaline, J., 1997. Un campement magdalénien au bord du lac de Neuchâtel: étude archéozoologique (secteur 1). Musée cantonal d'archéologie.

Morey, D., 1992. Size, shape and development in the evolution of the domestic dog. J. Archaeol. Sci. 19, 181-204.

Morey, D., 2006. Burying key evidence: the social bond between dogs and people. 
J. Archaeol. Sci. 33, 158-175

Morey, D., 2010. Dogs: Domestication and the Development of a Social Bond. Cambridge University Press, Cambridge.

Morey, D.F., Jeger, R., 2015. Paleolithic dogs: why sustained domestication then? J. Archaeol. Sci. Rep. 3, 420-428.

Morningstar, C., 1937. Effect of infection of the deciduous molar on the permanent tooth germ. J. Am. Dent. Assoc. Dent. Cosmos 24, 786-791.

Moulton, D.G., 1977. Minimum Odorant Concentrations Detectable by the Dog and Their Implications for Olfactory Receptor Sensitivity, Chemical Signals in Vertebrates. Springer, pp. 455-464.

Müller, W., 2005. The domestication of the wolf - the inevitable first? The first steps of animal domestication. In: Vigne, J.-D., Peters, J., Helmer, D. (Eds.), Oxbow Books, pp. 34-40.

Müller, W., Leesch, D., Bullinger, J., Cattin, M., Plumettaz, N., 2006. Chasse, habitats et rythme des déplacements: réflexions à partir des campements magdaléniens de Champréveyres et Monruz (Neuchâtel, Suisse). Bull. Soc. Prehist. Fr. 102, $741-752$.

Napierala, H., Uerpmann, H., 2012. A 'new'Palaeolithic dog from central Europe. Int. J. Osteoarchaeol. 22, 127-137.

Nehlich, O., Richards, M., 2015. Dietary reconstruction of the two skeletons from Oberkassel by stable carbon and nitrogen isostope analysis from bone collagen. In: Giemsch, L., Schmitz, R. (Eds.), The Late Glacial Burial from Oberkassel Revisited. Verlag Philipp von Zabern, pp. 1-18. Rheinische Ausgrabungen 72.

Nibali, L., 2015. Aggressive Periodontitis: microbes and host response, who to blame? Virulence 6, 223-228.

Nieminen, P., 2009. Genetic basis of tooth agenesis. J. Exp. Zool. B Mol. Dev. Evol. $312,320-342$

Nobis, G., 1981. Aus Bonn: Das Älteste Haustier Des Menschen. Unterkiefer Eines Hundes Aus Dem Magdaleniengrab Von Bonn-oberkassel. Das Reinische Landesmuseum Bonn, pp. 49-50.

Obersztyn, A., 1963. Experimental investigation of factors causing resorption of deciduous teeth. J. Dent. Res. 42, 660-674.

Oliver Foix, A., 2014. Perros en el culto, la economía y el prestigio de los iberos. Quaderns de prehistòria i arqueologia de Castelló 32, 43-61.

Olsen, S., 1985. Origins of the Domestic Dog: the Fossil Record. University of Arizona Press Tucson, USA.

Onar, V., 2005. Estimating the body weight of dogs unearthed from the vanyoncatepe necropolis in eastern anatolia. Turk. J. Vet. Anim. Sci. 29, 495-498.

Onar, V., Belli, O., 2005. Estimation of shoulder height from long bone measurements on dogs unearthed from the Van-Yoncatepe early iron age necropolis in Eastern Anatolia. RMV (Rev. Med. Vet.) (Toulouse) 156, 53-60.

Ovodov, N.D., Crockford, S.J., Kuzmin, Y.V., Higham, T.F., Hodgins, G.W., van der Plicht, J., 2011. A 33,000-year-old incipient dog from the Altai Mountains of Siberia: evidence of the earliest domestication disrupted by the Last Glacial Maximum. PLoS One 6, e22821.

Özmeriç, N., 2002. Localized alveolar bone necrosis following the use of an arsenical paste: a case report. Int. Endod. J. 35, 295-299.

Pacher, M., Stuart, J., 2009. Extinction chronology and palaeobiology of the cave bear (Ursus spelaeus). Boreas (Oslo) 38, 189-206.

Pang, J.-F., Kluetsch, C., Zou, X.-J., Zhang, A.-b., Luo, L.-Y., Angleby, H., Ardalan, A., Ekström, C., Sköllermo, A., Lundeberg, J., 2009. mtDNA data indicate a single origin for dogs south of Yangtze River, less than 16,300 years ago, from numerous wolves. Mol. Biol. Evol. 26, 2849-2864.

Pavlica, Z., Petelin, M., Juntes, P., Eržen, D., Crossley, D., Skalerič, U., 2008. Periodontal disease burden and pathological changes in organs of dogs. J. Vet. Dent. 25, 97-105.

Perri, A., 2016. A wolf in dog's clothing: initial dog domestication and Pleistocene wolf variation. J. Archaeol. Sci. 68, 1-4.

Pidoplichko, I., 1969. Pozdnepaleoliticheskie Zhilishcha Iz Kostei Mamonta Na Ukraine [Upper Paleolithic Dwellings of Mammoth Bones in Ukraine]. Naukova Dumka, Kiev.

Pionnier-Capitan, M., 2010. La domestication du chien en Eurasie: étude de la diversité passée, approches ostéoarchéologiques, morphométriques et paléogénétiques. University Dissertation, Lyon, France.

Pionnier-Capitan, M., Bemilli, C., Bodu, P., Célérier, G., Ferrié, J., Fosse, P., Garcià, M., Vigne, J.-D., 2011. New evidence for upper palaeolithic small domestic dogs in south-western Europe. J. Archaeol. Sci. 38, 2123-2140.

Pitulko, V.V., Kasparov, A.K., 2017. Archaeological dogs from the early holocene zhokhov site in the eastern siberian arctic. J. Archaeol. Sci. Rep. 13, 491-515.

Reimer, P.J., Bard, E., Bayliss, A., Beck, J.W., Blackwell, P.G., Bronk Ramsey, C., Buck, C.E., Cheng, H., Edwards, R.L., Friedrich, M., Grootes, P.M., Guilderson, T.P., Haflidason, H., Hajdas, I., Hatté, C., Heaton, T.J., Hoffmann, D.L., Hogg, A.G., Hughen, K.A., Kaiser, K.F., Kromer, B., Manning, S.W., Niu, M., Reimer, R.W., Richards, D.A., Scott, E.M., Southon, J.R., Staff, R.A., Turney, C.S.M., van der Plicht, J., 2013. IntCal13 and Marine13 radiocarbon age calibration curves 0-50,000 years cal BP. Radiocarbon 55 (4), 1869-1887.

Rütimeyer, L., 1861. Die Fauna der Pfahlbauten der Schweiz. Geschichte der Wilden und der Haus-Saugetiereal. 2016b. Neue Denkschriften der Algemeinne Schweizerische Geselschaft der Gesammten Naturwissenschaft 19, 97-143.

Romanes, G.J., 1887. Experiments on the sense of smell in dogs. Zool. J. Linn. Soc. 20 $65-70$.

Sablin, M., Khlopachev, G., 2002. The earliest Ice Age dogs: evidence from Eliseevichi. Curr. Anthropol. 43, 795-799.
Savolainen, P., Zhang, Y., Luo, J., Lundeberg, J., Leitner, T., 2002. Genetic evidence for an East-Asian origin of domestic dogs. Science 298, 1610-1613.

Shabestari, L., Taylor, G., Angus, W., 1967. Dental eruption pattern of the Beagle. J. Dent. Res. 46, 276-285.

Shannon, Laura M., Boyko, Ryan H., Castelhano, Marta, Corey, Elizabeth, Hayward, Jessica J., McLean, Corin, White, Michelle E., Abi Said, Mounir, Anita, Baddley A., Ikombe Bondjengo, Nono, Calero, Jorge, Galov, Ana Hedimbi, Marius, Imam, Bulu, Khalap, Rajashree, Lally, Douglas, Masta, Andrew, Oliveira, Kyle C., Pérez, Lucía, Randall, Julia, Minh Tam, Nguyen, TrujilloCornejo, Francisco J., Valeriano, Carlos, Sutter, Nathan B., Todhunter, Rory J. Bustamante, Carlos D., Boyko, Adam R., 2015. Genetic structure in village dogs reveals a Central Asian domestication. PNAS 112 (44), 13639. https://doi.org/ $10.1073 /$ pnas.1516215112.

Shipman, P., 2010. The animal connection and human evolution. Curr. Anthropol. 51, 519-538.

Shipman, P., 2015. How do you kill 86 mammoths? Taphonomic investigations of mammoth megasites. Quat. Int. 359, 38-46.

Stewart, J.R., Lister, Balles, A., Barnes, I., Dalén, L., 2010. Refugia revisited: individualistic responses of species in space and time. In: Proceedings of the Royal Society of London B: Biological Sciences, vol. 277, pp. 661-671.

Street, M., 1989. Ein frühmesolithischer Hund und Hundeverbiss an Knochen vom Fundplatz Bedburg-Konigshoven, Niederrhein in Das Aktuelle Thema: archäozoologie. Archaeol. Int. 12, 203-215.

Street, M., Balles, M., Weniger, B., 1994. Absolute chronologie des späten Paläolitikums und des Frühmesolithicums im nördlichen Rheinland. Arch. Kriminol. 24, 1-28.

Street, M., 1991. Bedburg-königshoven: a pre-boreal mesolithic site in the lower rhineland (Germany). CEP Res. Rep. 77, 256-270.

Street, M., 2002. Ein Wiedersehen mit dem Hund von Bonn-Oberkassel. Bonn. Zool Beitrage 50, 269-290.

Street, M., Jöris, O., Turner, E., 2012. Magdalenian settlement in the German Rhineland - an update. Quat. Int. 272-273, 231-250.

Street, M., Joris, O., 2015. The age of the Oberkassel burial in the context of climate environment and the late glacial settement history of the Rhineland. In: Giemsch, L., Schmitz, R. (Eds.), The Late Glacial Burial from Oberkassel Revisited. Verlag Philipp von Zabern, pp. 25-42. Rheinische Ausgrabungen 72.

Street, M., Napierala, H., Janssens, L., 2015. The late Palaeolithic dog from BonnOberkassel in context. In: Giemsch, L., Schmitz, R. (Eds.), The Late Glacia Burial from Oberkassel Revisited. Verlag Phiipp von Zabern, pp. 253-273. Rheinische Ausgrabungen 72

Tesson, S., 2013. Dans les forêts de Sibérie: février-juillet 2010. Gallimard, Paris.

Tetzlaff, D., Soulsby, C., Bacon, P., Youngson, A., Gibbins, C., Malcolm, I., 2007. Connectivity between landscapes and riverscapes-a unifying theme in integrating hydrology and ecology in catchment science? Hydrol. Process. 21, 1385-1389.

Thalmann, O., Shapiro, B., Cui, P., Schuenemann, V., Sawyer, S., Greenfield, D., Germonpré, M., Sablin, M., López-Giráldez, F., Domingo-Roura, X., Napierala, H. Uerpmann, H., Loponte, D., Acosta, A., Giemsch, L., Schmitz, R., Worthington, B., Buikstra, J., Druzhkova, A., Graphodatsky, A., Ovodov, N., Wahlberg, N., Freedman, A., Schweizer, R., Koepfli, K., Leonard, J., Meyer, M., Krause, J. Pääbo, S., Green, R., Wayne, W., 2013. Complete mitochondrial genomes of ancient canids suggest a European origin of domestic dogs. Science 342, $871-874$.

Trinkhaus, E., 2015. The appendicular skeletal remains of Oberkassel 1 and 2. In Giemsch, L., Schmitz, R. (Eds.), The Late Glacial Burial from Oberkassel Revisited. Verlag Philipp von Zabern, Rheinische Ausgrabungen 72, pp. 75-132.

van Doorn, N., Hollund, H., Collins, M., 2011. A novel and non-destructive approach for ZooMS analysis: ammonium bicarbonate buffer extraction. Archaeologica and Anthropological Sciences 3, 281-289.

Van Valkenburgh, B., 1988. Incidence of tooth breakage among large, predatory mammals. Am. Nat. 131, 291-302.

Vandevelde, M., Kristensen, B., Braund, K., Greene, C., Swango, L., Hoerlein, B., 1980. Chronic canine distemper virus encephalitis in mature dogs. Vet. Pathol. 17, $17-29$.

Verstraete, F., van Aarde, R., Niewoudt, B., Mauer, E., Kass, P., 1996a. The dental pathology of feral cats on Marion Island, part I: congenital, developmental and traumatic abnormalities. J. Comp. Pathol. 115, 265-282.

Verstraete, F., van Aarde, R., Niewoudt, B., Mauer, E., Kass, P., 1996b. The denta pathology of feral cats on Marion Island, part II: periodontitis, external odontoclastic resorption lesions and mandibular thickening. J. Comp. Pathol. 115, 283-297.

Verworn, M., Steinmann, G., Bonnet, R., 1919. Der diluviale menschenfund von Obercassel bei Bonn. JF Bergmann, Bonn.

Vigne, J.-D., 2011. The origins of animal domestication and husbandry: a major change in the history of humanity and the biosphere. Comptes Rendus Biol. 334 171-181.

Vila, C., Maldonado, J.E., Wayne, R.K., 1999. Phylogenetic relationships, evolution, and genetic diversity of the domestic dog. J. Hered. 90, 71-77.

Vonholdt, B., Pollinger, J.P., Lohmueller, K.E., Han, E., Parker, H.G., Quignon, P., Degenhardt, J.D., Boyko, A.R., Earl, D.A., Auton, A., Reynolds, A., 2010. Genomewide SNP and haplotype analyses reveal a rich history underlying dog domestication. Nature 464, 898-902.

Wang, G., Zhai, W., Yang, H., Fan, R., Cao, X., Zhong, L., Wang, L., Liu, F., Wu, H., Cheng, L., Poyarkov, A., Poyarkov, N., Tang, S., Zhao, W., Gao, Y., Lv, X., Irwin, D. 
Savolainen, P., Wu, C., Zhang, Y., 2013. The genomics of selection in dogs and the parallel evolution between dogs and humans. Nat. Commun. 4, 1860-1870.

Wapnish, P., Hesse, B., 1993. Pampered pooches or plain pariahs? The Ashkelon dog burials. Biblic. Archaeol. 55-80.

Watson, A., 1994. Diet and periodontal disease in dogs and cats. Aust. Vet. J. 71,
$313-318$.

Zhang, Y.R., Du, W., Zhou, X.-D., Yu, H.-Y., 2014. Review of research on the mechanical properties of the human tooth. Int. J. Oral Sci. 6, 61.

Zeder, M., 2012. The domestication of animals. J. Anthropol. Res. 68, 161-190. 